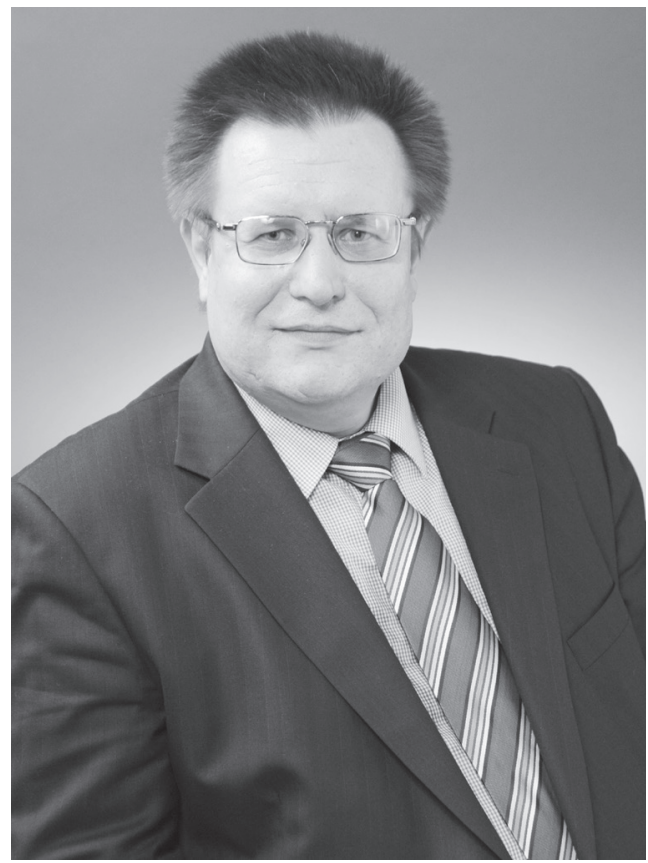

УДК: 316.422' 3.061.1 СС (477)

DOI: https://doi.org/10.32689/2617-

2224-2019-18-3-116-127

Валевський Олексій Леонідович, доктор наук з державного управління, провідний науковий співробітник, Національний інститут стратегічних досліджень, 01030, м. Киів, вул. Пирогова, 7-а, тел.: + 38 (050) 65438 98, e-mail:walewsk@gmail.com

ORCID: 0000-0003-0403-0277

Валевский Алексей Леонидович, доктор наук государственного управления, ведущий научныий сотрудник, Наииональный институт стратегических исследований, 01030, г. Киев, ул. Пирогова, 7-а, тел.: +38 (050) 65438 98, e-mail: waleresk@gmail.com

ORCID: 0000-0003-0403-0277

Valevskyi Oleksii Leonidovich,

Doctor of Science in Public Administration, Senior Researcher, National Institute for Strategic Stugies, 01030, Kyiv, Str. Pirohova, 7-a, tel.: + 38 (050) 65438 98, e-mail: walewsk@gmail.com

ORCID: 0000-0003-0403-0277

\title{
ПРОБЛЕМИ ЦІННІСНИХ ТРАНСФОРМАЦІЙ ТА СУСПІЛЬНОÏ КОНСОЛІДАЦІЇ У КОНТЕКСТІ ЄВРОПЕЙСЬКОГО ВИБОРУ УКРАЇНИ
}

Анотація. Дослідницьке завдання полягає в аналізі ціннісних трансформацій, які відбуваються у громадській свідомості та пов'язуються з напрямом європейської інтеграції України. Оскільки процеси ціннісних трансформацій і формування ідентичності є нелінійними, то для їх верифікації у громадській свідомості, окрім кількісних методів, необхідно застосовувати архетиповий підхід.

Доведено, що шлях європейської інтеграції для України пов’язується не лише з економічними та інституційними перетвореннями, а також із необхідністю опанування європейськими цінностями та поведінковими моделями, на яких будуються економічна, соціальна та політична сфери функціонування європейської співдружності.

Показано, що внаслідок російської агресії та посилення євроінтеграційних тенденцій відбуваються ціннісні зміни в оцінках українськими громадянами суспільних процесів та світоглядних орієнтацій. Суттєво зменшується 
привабливість інтеграційних моделей за участю РФ, натомість збільшується кількість прихильників європейського напряму.

Доводиться, що ціннісні трансформації відбуваються повільно, і цей процес не є лінійним. Однак можна стверджувати, що умовний набір “європейських цінностей” поступово збільшує кількість своїх прихильників серед громадян.

Масштабні суспільні пертурбації, які пов'язані з агресією РФ на Донбасі та економічною кризою, сприяли формуванню у громадській свідомості запиту на цінності єдності та консолідації. Проте на цей момент потреба у цінностях консолідації та єдності залишається багато в чому не реалізованою.

Робиться висновок, що необхідність забезпечення незворотності процесу ціннісних трансформацій змушує під іншим кутом зору сприймати культурну діяльність. Доводиться, що динамічний розвиток культури має ключове значення для успішної модернізації України та забезпечення сталого розвитку.

Ключові слова: асоціація України з СС, ціннісні трансформації, консолідація суспільства, культурна політика, модернізація суспільства, сталий розвиток, архетиповий підхід.

\section{ПРОБЛЕМЫ ЦЕННОСТНЫХ ТРАНСФОРМАЦИЙ И ОБЩЕСТВЕННОЙ КОНСОЛИДАЦИИ В КОНТЕКСТЕ ЕВРОПЕЙСКОГО ВЫБОРА УКРАИНЫ}

Аннотация. Исследовательское задание публикации состоит в анализе ценностных трансформаций, происходящих в общественном сознании, которые вызваны европейской интеграцией Украины. Поскольку процессы ценностных трансформаций и формирования идентичности являются нелинейными, то для их верификации, кроме количественных методов, необходимо применять архетипный подход.

Доказано, что европейская интеграция Украины связана не только с экономическими и институциональными преобразованиями, а также с необходимостью освоения европейских ценностей и поведенческих моделей, на которых строятся экономическая, социальная и политическая сферы функционирования европейского содружества.

Показано, что в результате российской агрессии и усиления евроинтеграционных тенденций происходят ценностные изменения в оценках украинскими гражданами общественных процессов и мировоззренческих ориентаций. Существенно уменьшается привлекательность интеграционных моделей с участием РФ, зато увеличивается количество сторонников европейского направления.

Доказано, что ценностные трансформации происходят медленно, и этот процесс не является линейным. Однако можно утверждать, что условный набор “европейских ценностей” постепенно увеличивает количество своих сторонников среди граждан. 
Масштабные общественные пертурбации, связанные с агрессией РФ на Донбассе и экономическим кризисом, способствовали формированию в общественном сознании запроса на ценности единства и консолидации. Однако на данный момент потребность в ценностях консолидации и единства остается во многом не реализованной.

Делается вывод, что необходимость обеспечения необратимости процесса ценностных трансформаций заставляет под другим углом зрения воспринимать культурную деятельность. Доказывается, что динамичное развитие культуры имеет ключевое значение для успешной модернизации Украины и обеспечения устойчивого развития.

Ключевые слова: ассоциация Украины с ЕС, ценностные трансформации, консолидация общества, культурная политика, модернизация общества, устойчивое развитие, архетипный поход.

\section{PROBLEMS OF VALUE TRANSFORMATIONS AND PUBLIC CONSOLIDATION IN THE CONTEXT OF UKRAINE'S EUROPEAN CHOICE}

Abstract. The research task of the publication is to analyze the value transformations occurring in the public consciousness, which are caused by the European integration of Ukraine. Since the processes of value transformations and the formation of identity are non-linear, in addition to quantitative methods, it is necessary to apply an archetypal approach to verify them.

It is proved that the European integration of Ukraine is connected not only with economic and institutional transformations, but also with the need to master European values and behavioral models on which the economic, social and political spheres of the European community are built.

It is shown that as a result of the Russian aggression and the strengthening of European integration tendencies, value changes occur in the assessments of Ukrainian citizens of social processes and worldview orientations. The attractiveness of integration models with the participation of the Russian Federation is significantly reduced, but the number of supporters of the European direction is increasing.

It is proved that value transformations occur slowly, and this process is not linear. However, it can be argued that the conditional set of "European values" is gradually increasing the number of its supporters among citizens.

Large-scale public perturbations that are associated with Russian aggression in the Donbass and the economic crisis have contributed to the formation of a request for unity and consolidation in the public consciousness. However, at the moment the need for values of consolidation and unity remains largely unfulfilled.

It is concluded that the need to ensure the irreversibility of the process of value transformations makes it necessary to perceive cultural activities from a different angle. It is proved that the dynamic development of culture is of key importance for the successful modernization of Ukraine and ensuring sustainable development. 
Keywords: association of Ukraine with the EU, value transformations, consolidation of society, cultural policy, modernization of society, sustainable development, archetypical approach.

Постановка проблеми. У 2014 р. 3 перемогою в Україні Євромайдану було проголошено курс на європейську інтеграцію. Набула чинності Угода про Асоціацію України та СС, яка закріплювала шлях європейської інтеграції. У Преамбулі до Угоди наголошується, що іiї створення базується на тому, що Україна та країни - члени ЄС розділяють спільні цінності. Вказується, що “Україна як європейська країна поділяє спільну історію й спільні цінності з державами - членами Європейського Союзу ( $\mathrm{CC})$ і налаштована підтримувати ці цінності". Також у Преамбулі стверджується, що між Україною та СС існують відносини, які грунтуються на спільних цінностях. Слід звернути увагу на те, що тут дається вичерпний перелік зазначених цінностей. А саме, повага до демократичних принципів, верховенство права, добре врядування, права людини і основоположні свободи, у тому числі права осіб, які належать до національних меншин, повага до різноманітності, людської гідності та відданість принципам вільної ринкової економіки [1]. Тут же відзначається "важливість, яку надає Україна своїй європейській ідентичності”. Важливо зауважити, що в Преамбулі вказується, що інтеграція України з Європейським Союзом “залежатиме від досягнень України в забезпеченні поваги до спільних цінностей і прогресу в наближенні до ЄС у політичній, економічній та правовій сферах". На- самкінець, у переліку цілей Асоціації на першому місці вказується сприяння зближенню України та $\mathrm{CC}$, яке грунтується на спільних цінностях.

Таким чином, шлях європейської інтегращії для України пов'язується не лише з економічними та інституційними перетвореннями. Цей шлях має супроводжуватися ціннісними трансформачіями у громадській свідомості $i$ поведінкових моделях. Позаяк Угода приділяє ціннісним трансформаціям таке ж велике значення, як соціально-економічним, правовим та інституційним змінам.

У 2017 р. Кабінет Міністрів України затвердив оновлений План заходів із виконання Угоди про асоціацію Україна-СС. Цим Планом визначається, що євроінтеграція є невід'ємною частиною стратегічного планування та формування політики кожного міністерства. План заходів - це масштабний документ, у якому сформульовані 1943 завдання, що охоплюють 27 сфер. За виконання завдань відповідальні 106 органів влади України [2]. Уряд регулярно публікує звіти про виконання завдань, пов'язаних з Угодою. Так, станом на перше півріччя 2018 року Україна виконала $41 \%$ річного плану заходів із виконання Угоди [3].

Водночас у дискусіях навколо виконання Україною завдань, пов'язаних з Угодою, саме проблемі формування цінностей не приділяється належна увага. Це можна пояснити тим, що ціннісні трансфор- 
мації безпосередньо не пов'язані ані $з$ діяльністю органів влади, ані 3 інституційними перетвореннями. Однак нехтувати цим фактором євроінтеграційного процесу недоречно, оскільки йому надається велике функціональне значення. Угода виходить із того постулату, що критерієм успішності інтеграції України з $\mathrm{CC}$ є рівень опанування нею базовими європейськими цінностями в політичній, економічній та правовій сферах. Насамкінець, у переліку цілей Асоціації на першому місці вказується сприяння зближенню України та $\in C$, яке грунтується на спільних цінностях.

Метою статті є аналіз ціннісних трансформацій, які відбуваються у громадській свідомості і пов'язуються з напрямом європейської інтеграції України. Оскільки процеси ціннісних трансформацій i формування ідентичності є нелінійними і вказують на складні та неоднозначні тенденції у громадській свідомості, то для їхньої верифікації, окрім кількісних методів, необхідно застосовувати архетиповий підхід.

\section{Виклад основного матеріалу.} Перше, що привертає увагу, коли йдеться про ціннісні трансформації протягом останніх років, - це послаблення впливу ідеологем "руського міру” (РM) на громадську свідомість українського суспільства. Так, моніторингове дослідження Інституту соціології НАН України у 2013 р. зафіксувало аномально високе позитивне ставлення громадян України до Путіна - середній бал інтегральної оцінки (за шкалою “1” - найнижча, “10” - найвища оцінка) становив 5,8 балів. До речі, тодішній український президент отримав набагато меншу оцінку - всього 3,6 балів. У 2017 р. оцінка Путіна українськими громадянами впала до 2,9 балів [4, с. 498]. Проте, беручи до уваги великі масштаби руйнівних наслідків російської агресії, все одно такий показник не може не викликати стурбованість. Однак зазначена динаміка оцінок показує, що в громадській свідомості посилюється процес неприйняття ідеології РМ.

До 2014 р. в українському суспільстві сформувалася значна кількість громадян, які підтримували пріоритетний характер зовнішньополітичного партнерства з РФ. Зокрема, за даними опитувань Центру Разумкова, у 2009 р. їхня кількість досягла рекордної позначки 51,1 \%. Варто звернути увагу на фактори, які на той час, на думку респондентів, могли б сприяти зближенню України i Росії. Це - спільне історичне минуле $(42,7 \%)$, родинні зв'язки між жителями обох країн $(41,7 \%)$, близькість культур (24,6 \%) [5, с. 72-75]. Традиційно прихильники посилення контактів з РФ - це жителі східних і південних областей. Однак до 2014 р. така прихильність набувала подекуди гіпертрофованих форм. Так, за даними Центру Разумкова, у 2009 р. 65,7 \% представників умовної “слов'янської спільноти” Криму (громадяни України, які є етнічними українцями або росіянами) були переконані, що українці і росіяни єдиний народ, а 44,2 \% не вважали себе представниками української політичної нації [6].

Проте 2014 р., у результаті осмислення причин російської агресії та посилення євроінтеграційних про- 
цесів, відбуваються зміни в оцінках українськими громадянами зовнішньополітичних орієнтацій. Ілюстрацією сказаного є динаміка ставлення громадян до вступу України до Митного союзу. Нагадаємо, що протягом 2013 р. проводилася масована інформаційна обробка свідомості українських громадян щодо вступу України до Митного союзу. Це дало свої результати - на той час $45 \%$ громадян позитивно ставилися до вступу України до Митного союзу, $25 \%$ - негативно. У 2017 р. кількість тих, хто позитивно оцінювали вступ України до Митного союзу, зменшилося до $22 \%$, натомість кількість противників такої інтеграційної моделі збільшилася до 57 \% [7, с. 501]. Аналогічна тенденція спостерігається у зміні ставлення до інтеграційних моделей, спрямованих на зближення України із західним світом. Так, у 2013 р. 28 \% громадян негативно ставилися до ідеї вступу України до Європейського Союзу. У 2017 р. таких було $24 \%$. Водночас суттєво зросла кількість тих, хто підтримує вступ України до $\mathrm{CC}$ із $41 \%$ у 2013 р. до $54 \%$ у 2017 р. Аналогічні тенденції спостерігаються у ставленні громадян до ідеї вступу України до НАТО. Так, кількість тих, хто негативно сприймав цю ідею, зменшилася з 54 \% у 2013 р. до 35 \% у 2017 р. Водночас число прихильників вступу до Альянсу зросло з $14 \%$ у 2013 р. до $40 \%$ у 2017 р. [8, c. 502].

Загалом є підстави стверджувати, що протягом останніх років у громадській свідомості посилюються прозахідні настрої. Згідно з даними дослідження, проведеного наприкінці 2018 р., “за” вступ України до
НАТО висловилися 46,3 \% громадян, “проти” - 31,6 \%. Відповідно, вступ до Європейського Союзу підтримують 58,1 \% громадян, не підтримують $-23,9$ \% [9]. Втім отримані дані не повинні справляти враження щодо консолідованої підтримки населенням західного вектора інтеграції. Тут необхідно враховувати, що згідно 3 даними зазначеного опитування, 51 \% жителів південного та 53 \% східного регіонів не підтримують вступу до НАТО. Отже, 41 \% жителів південного і $40 \%$ жителів східного регіонів скептично ставляться до вступу до ЄС. Такий регіональний розподіл відповідей підводить до висновку, що ціннісні трансформації відбуваються повільно і цей процес не є лінійним. У суспільстві зберігаються певні ціннісні анклави, які не сприймають зміни.

Дослідження орієнтацій українських громадян показує, що умовний набір “європейських цінностей” поступово збільшує кількість своїх прихильників. Так, тематичне дослідження "Українське суспільство та європейські цінності”, проведене у 2017 р. Інститутом Горшеніна у співпраці з Представництвом Фонду ім. Ф. Еберта в Україні, показало, що домінуючими у свідомості українців є цінності особистого добробуту здоров'я, успіх, достаток, щаслива сім'я, відсутність стресів, особистісний розвиток. Далі йдуть цінності, що пов'язані з патерналізмом, якісні та безкоштовні освіта і медицина, гідні пенсії, соціальні виплати, забезпеченість робочими місцями, співмірні отримуваним доходам ціни. I тільки в останню чергу респонденти вказували на цінності, які можна 
позначити як “європейські” - верховенство права, демократія, свобода слова, чесність/прозорість, прагнення надати рівні можливості усім громадянам тощо [10, с. 13]. Результати цього дослідження показали, що європейські цінності є привабливими для українців, й необхідність їхнього впровадження знаходить одностайну підтримку як серед прихильників, так і серед противників вступу до ЄC. Зокрема, респонденти вказали, що найбільш затребуваною цінністю є верховенство права. Далі вказуються такі цінності, як рівність перед законом, права людини, демократія. Водночас, вказують автори дослідження, респонденти погоджуються, що “шлях до реалізації зазначених цінностей буде тривалим, адже, на їхню думку, в нашій державі відсутні справедливі суди, законодавча система вкрай недосконала, у свідомості громадян немає ані поваги, ані страху перед законом”. Ще один висновок, якого дійшли автори зазначеного дослідження, - “базові європейські цінності сприймаються українцями як благо, до якого потрібно прагнути та яке в перспективі може вплинути на позитивні суспільні тенденціі. Для українців характерним є те, що вони схильні гіпотетично підтримувати ці цінності, але у повсякденній практиці їх втілюють вибірково” [11, с. 19] .

Починаючи з 2014 р., у громадській свідомості відбуваються ціннісні трансформації під впливом освоєння нових економічних і соціальних практик, пов'язаних 3 євроінтеграційним шляхом. Опанування цими практиками є актуальним завданням 3 огляду на необхідність адаптації українського суспільства до європей- ського економічного і гуманітарного простору.

Також, як зазначалося, цей процес натрапляє на необхідність подолання багатьох складнощів, фобій та забобонів масової свідомості. Зокрема, фіксуються суперечливі тенденції щодо опанування громадянами цінностей приватної ініціативи та вільного ринку. За результатами опитування, проведеного Соціологічною групою “Рейтинг” у 2019 р., майже 40 \% українців хотіли б мати власну справу. 3 іншого боку, половина опитаних (48 \%) не висловлювали таких бажань. Тоді як у 2013 р. тих, хто бажав зайнятися власною справою, було лише 27 \%, а тих, хто не хотів цього, - 63 \%. Тож поступово збільшується кількість прихильників приватної ініціативи [12]. Проте ця тенденція ще не доводить, що у громадській свідомості зникають настрої патерналізму. Так, за результатами опитування 2019 р. більшість громадян (64%) дотримувалися думки, що роль держави у розвитку економіки полягає у забезпеченні рівності доходів і соціальної справедливості. I тільки 27 \% вважали, що держава повинна забезпечувати свободу розвитку та чесні правила конкуренції. Як бачимо, спостерігається ефект “роздвоєності”. 3 одного боку, зростає кількість громадян, які бажають реалізувати приватну ініціативу, а відтак і кількість прихильників ліберальних поглядів. 3 іншого - більшість дотримується суто патерналістських установок i вимагає від держави забезпечити рівність доходів.

Для демонстрації масштабу проблеми культурного освоєння євро- 
пейських цінностей, яка стоїть перед суспільством, варто звернутися до специфіки розуміння населенням змісту базових цінностей, пов'язаних із правами людини. Результати дослідження “Що українці знають та думають про права людини: оцінка змін (2016-2018)” показує, що незважаючи на те, що населення має доволі високий рівень підтримки цінностей прав людини, існує істотний дисбаланс у їхньому сприйнятті [13]. Так, дві третини населення пріоритетними зазначають соціально-економічні права, і це не дивно на тлі високого рівня бідності в країні. Як стверджують автори дослідження, проблемою $\epsilon$ те, що пересічна людина не зовсім усвідомлює первинність політичних та громадянських прав. Також автори зазначають, що 50-60 \% українців виправдовують обмеження прав наркозалежних, колишніх засуджених, людей із непопулярними політичними поглядами, ромів та представників ЛГБТ-спільноти. Більш того, ситуація з готовністю до обмеження прав осіб, що належать до цих соціальних груп, погіршилася. Проведене дослідження також засвідчило зневіру людей у можливостях відстоювати свої права перед органами влади. Загалом отримані результати підтверджують необхідність продовження системної просвітницької та культурної роботи як із донесення громадянам змісту їхніх прав, так і необхідності дотримання прав людини органами влади.

Масштабні суспільні пертурбації, що пов'язані з агресією РФ на Донбасі та економічною кризою, сприяли формуванню у громадській свідомості запиту на цінності єдності та консолідащії. Так, за результата- ми опитування у 2019 р. 28 \% громадян зазначили, що країні найбільше бракує єдності. Щодо потенційних загроз, то громадяни також досить гостро відчувають загрозу деконсолідації суспільства. Так, у переліку потенційних загроз 33 \% вказали на “розвал країни". Найбільш гостро це відчувають мешканці східного та південного регіонів. На загрозу виникнення безвладдя та анархії вказали 24 \% громадян [14]. Проте на даний момент потреба у цінностях консолідації та єдності залишається багато в чому не реалізованою, позаяк ані політичні сили, ані громадські інститути через різні причини не можуть об'єднати суспільство, запропонувавши реалістичний набір цінностей та поведінкових моделей.

Необхідність забезпечення незворотності процесу ціннісних трансформацій змушує під іншим кутом сприймати культурну діяльність. Адже саме культура має належний ціннісний і духовний потенціал для збереження національних та ціннісних ідентичностей і формування світогляду сучасної людини. Нехтування можливостями культури у формуванні сучасної людини, віддаючи перевагу, передусім, вирішенню економічних та соціальних проблем, $є$ недалекоглядною позицією.

Динамічний розвиток культури має ключове значення для успішної модернізації України та сталого розвитку. Потрібно якомога швидше відмовитися від помилкової точки зору, що успіх реформ лежить тільки в економічній та соціальній площині. Успішними реформи можуть бути тільки тоді, коли вони супроводжуються ефективною політикою 
держави в духовній сфері. Саме цих установок бракувало українським реформаторам, які помилково пов'язували завдання реформ тільки зі збільшенням матеріального споживання. Водночас такі завдання, як сприяння ціннісним трансформаціям, розвиток креативного потенціалу суспільства, створення умов для формування творчого середовища та нових форм громадської організації, не потрапляли до уваги реформаторів.

Дослідження громадської думки показують, що в українців зміцнюється упевненість, що в модернізаціі українського суспільства необхідно орієнтуватися на європейські цінності суспільного устрою. Водночас громадяни усвідомлюють, що в сучасних умовах бідності, корупції в центральних і місцевих органах влади, низького рівня правової та політичної культури неможливо “одномоментно” впровадити європейські цінності у суспільну практику. Для цього необхідна копітка і системна робота, що розрахована на значний проміжок часу.

\section{Висновки.}

1. Починаючи 32014 р., у контексті спротиву агресії РФ і з початком реалізації Асоціації України 3 ЄC, відбуваються зміни у ціннісному сприйнятті громадською думкою суспільно-політичних процесів. Власне необхідність таких трансформацій зумовлюється самою Асоціацією, де в Преамбулі стверджується, що шлях європейської інтеграції для України пов’язується, передусім, 3 опануванням ціннісного базису, на якому побудована європейська співдружність. Наводиться перелік таких иінностей, як: дотримання демократичних приниипів, верховенство права, добре врядування, права людини і основоположні свободи, у тому числі начіональних меншин, повага до різноманітності, людської гідності та відданість принципам ринкової економіки.

2. Результати моніторингових досліджень дають можливість визначити деякі вектори ціннісних трансформацій у громадській свідомості, що відбуваються. Так, після 2014 р. зруйнувалося уявлення щодо пріоритетного характеру зовнішньополітичного партнерства України з РФ. Аналогічний негативізм фіксується щодо інтеграційних моделей за участю РФ, зокрема Митного союзу. Одночасно збільшується кількість прихильників західного вектора інтеграції України. Також моніторингові дослідження показують, що у східних та південних областях країни зберігається значна кількість громадян, які прихильно ставляться до ідеологем “руського міра”. Тож иіннісні трансформацї відбуваються повільно, $i$ чей прощес не є лінійним, тому в громадській свідомості зберігаються певні “иіннісні анклави”.

3. Дослідження орієнтацій українських громадян показує, що умовний набір “європейських цінностей” поступово збільшує кількість своїх прихильників. Водночас цей процес натикається на необхідність подолання багатьох фобій та забобонів у масовій свідомості. Доводиться мати справу зі своєрідним ефектом "роздвоєності”, коли декларується відданість “европейським иінностям”, а на практиці поведінкові моделі тяжіють до патерналістських або авторитар- 
них установок. Порочні наслідки цієї "роздвоєності" можна побачити, зокрема, у сфері прав людини, де відбувається чимало порушень.

4. Одним із факторів трансформацій, що відбуваються, стало формуваннязапиту вгромадській свідомості на иінності єдності та консолідащії. Найбільш гостро актуальність таких цінностей відчувають мешканці східного та південного регіонів. Проте на даний момент цей запит залишається багато в чому не реалізованим. Ані політичні сили, ані громадські інститути в силу різних причин не можуть об'єднати суспільство, запропонувавши вичерпний набір цінностей та поведінкових моделей.

5. Необхідність забезпечення незворотності процесу ціннісних трансформацій змушує під іншим кутом сприймати культурну діяльність. Адже саме культура має належний ціннісний потенціал для формування світогляду сучасної людини. Вкотре доводиться зазначати, що нова культурна політика повинна стати засобом розвитку інновачійного потенщіалу суспільства та його консолідащії навколо щинностей прогресу. Саме така культурна політика здатна протистояти впливу дезінтеграційних процесів.

Реальний масштаб проблем, 3 якими доводиться стикатися у справі формування нової системи цінностей у свідомості українських громадян, не має аналогів у минулому. Тут провідникам культурної і гуманітарної політики доводиться діяти в умовах, які старі шаблони та підходи не працюють. Тому існує гостра необхідність формування нової методології проектування та впровадження гуманітарної і культурної політики, адже йдеться про завдання необхідності зміни деструктивних установок самосвідомості великої кількості людей та формування нової системи цінностей.

\section{СПИСОК ВИКОРИСТАНИХ ДЖЕРЕЛ}

1. Угода про Асоціацію між Україною та Європейським Союзом [Електронний ресурс]. - Режим доступу : https://zakon.rada.gov.ua/laws/ show/984_011

2. План заходів з виконання Угоди про Асоціацію між Україною та Європейським Союзом. Євроінтеграційний портал [Електронний ресурс]. Режим доступу : https://eu-ua.org/ plan-zakhodiv-z-vykonannia-uhody

3. За перше півріччя 2018 року Україна виконала $41 \%$ плану щодо Угоди про асоціацію [Електронний ресурс]. - Режим доступу: https://www.pravda.com.ua/news/ 2018/09/19/7192587/

4. Українське суспільство: моніторинг соціальних змін: зб. наук. пр. Вип. 4 (18), Ін-т соціології НАН України. - К., 2017. - 599 с.

5. Українсько-російські відносини в оцінках громадян України. Всеукраїнське соціологічне опитування Центру Разумкова [Електронний ресурс] / / Нац. безпека і оборона. 2009. - № 4. - С. 72-84. - Режим доступу : http://razumkov.org.ua/ uploads/journal/ukr/NSD108_2009_ ukr.pdf

6. Кримський соціум: лінії поділу та перспективи консолідації. Аналітична доповідь Центру Разумкова [Електронний ресурс] // Нац. безпека i оборона. - 2009. № 5. - С. 4-5. - Режим доступу : http://razumkov.org.ua/uploads/ 
journal/ukr/NSD109_2009_ukr. pdf

7. Українське суспільство: моніторинг соціальних змін.

8. Українське суспільство: моніторинг соціальних змін.

9. “Соціально-політична ситуація в Україні” (2018). Результати дослідження КМІС, СОЦИС та Центру Разумкова [Електронний ресурс]. Режим доступу: https://www.kiis. com.ua/ ?lang $=$ ukr\&cat $=$ news \&id $=78$ $4 \&$ page $=4$

10. "Українське суспільство та європейські цінності”. Звіт за результатами соц. дослідження проведеного Ін-том Горшеніна у співпраці 3 Представництвом Фонд ім. Фрідріха Еберта в Україні, 2017 [Електронний ресурс] // Фонд ім. Фрідріха Еберта. Предст-во в Україні. - 42 с. - Режим доступу : http://fes.kiev.ua/n/cms/fileadmin/ upload2/JEvropeiski_cinnosti tables_and_diagrams_MR_.pdf

11. Українське суспільство та європейські цінності.

12. Оцінка відносин держави і бізнесу. Березень 2019. Соціологічна група "Рейтинг" [Електронний ресурс]. - Режим доступу : http:// ratinggroup.ua/research/ukraine/ ocenka_otnosheniy_gosudarstva_i biznesa_mart_2019.html

13. Що українці знають і думають про права людини: оцінка змін (20162018) [Електронний ресурс] / Peзюме дослідж. [С. Коліушко, М. Паращевін, В. Яворський]; за заг. ред. Т. Печончик. - К., 2018. - 96 с. Режим доступу: https://dif.org.ua/ uploads/pdf/19484532155c0fae449ca ba5.69437042.pdf

14. Настрої та оцінка загроз українцями. Соціологічна група "Рейтинг", 2019 [Електронний ресурс]. Режим доступу: http://ratinggroup.ua/research/ukraine/ nastroeniya_i_ocenka_ugroz_ ukraincami.html

\section{REFERENCES}

1. Association Agreement between Ukraine and the European Union, [Online], available at: https://zakon. rada.gov.ua/laws/show/984_011

2. Action Plan on Implementation of the Association Agreement between Ukraine and the European Union. Eurointegration portal, [Online], available at: https://eu-ua.org/plan-zakhodiv-z-vykonannia-uhody

3. During the first half of 2018 , Ukraine fulfilled $41 \%$ of the Association Agreement plan, [Online], available at: https://www.pravda.com.ua/ news/2018/09/19/7192587/

4. Ukrainian society: monitoring social change. Collection of scientific works. Issue 4 (18), Institute of Sociology of the National Academy of Sciences of Ukraine - Kyiv - 2017.

5. Ukrainian-Russian relations in the estimations of Ukrainian citizens. AllUkrainian sociological survey of the Razumkov Center // National Security and Defense. - 2009. - № 4. P. 72-84, [Online], available at: http:// razumkov.org.ua/uploads/journal/ ukr/NSD108_2009_ukr.pdf

6. Crimean society: dividing lines and prospects for consolidation. Analytical Report of the Razumkov Center // National Security and Defense. 2009. - № 5. - P. 4-5. [Online], available at: http://razumkov.org.ua/ uploads/journal/ukr/NSD109_2009_ ukr.pdf

7. see: Ukrainian society: monitoring social change

8. see: Ukrainian society: monitoring social change

9. "Socio-political situation in Ukraine" (2018). The results of the study of KIIS, SOCIS and the Razumkov 
Center, [Online], available at: https:// www.kiis.com.ua/?lang $=\mathrm{ukr} \& \mathrm{cat}=\mathrm{ne}$ ws\&id $=784 \&$ page $=4$

10. "Ukrainian society and European values" (2017). Report on the results of a sociological study conducted by the Gorshenin Institute in cooperation with the Friedrich Ebert Foundation in Ukraine. // Friedrich Ebert Foundation. Representation in Ukraine, [Online], available at: http://fes.kiev. $\mathrm{ua} / \mathrm{n} / \mathrm{cms} /$ fileadmin/upload2/JEvropeiski_cinnosti_tables_and_diagrams_MR_pdf

11. see: "Ukrainian society and European values" (2017)

12. Assessment of relations between the state and business. March 2019. Sociological group "Rating", [Online], avai- lable at: http://ratinggroup.ua/ research/ukraine/ocenka_otnosheniy_gosudarstva_i_biznesa mart 2019.html

13. What Ukrainians know and think about human rights: assessment of changes (2016-2018) / Summary of research. [C. Koliushko, M. Paraschevin, V. Yavorsky]; under the edit T. Pechonchik. - Kyiv, 2018. - 96 p., [Online], available at: https://dif.org. ua/uploads/pdf/19484532155c0fae44 9caba5.69437042.pdf

14. Confidence and assessment of threats by Ukrainians. Sociological group "Rating" (2019), [Online], available at: http://ratinggroup.ua/research/ ukraine/nastroeniya_i_ocenka_ ugroz_ukraincami.html 